\title{
Empowerment Of Women Through Information And Communication Technology [ICT]
}

\author{
S. M. Khalid Jamal \\ Department of Computer Science \\ University of Karachi
}

\begin{abstract}
Our world has seen enormous improvements in mobile telephony, the internet, and ebusiness. Information and Communication Technology (ICT) play a critical and core role in today's society. All over the world nations have recognized information and communication Technology (ICT) as a powerful tool in accelerating the economic activity, efficient governance and developing human resources. Whether it's the electronic form of conducting business or social/professional networking over the World Wide Web, ICT has proved that it is a basic requirement for social and economic development. To increase the flow of Information and improving communications and to increase possibilities and opportunities, ICT infrastructure is a rudimentary need. ICT has proved that it is one of the major difference between developed and developing countries. Take for example India. India has achieved the status of the world's 4th biggest economy, major fraction of which is basically IT driven. The information and communication technology could be used to empower the Women in Pakistan by making the resources available to them at home, where a nearby area / residential based environment could be created for working at home where they could fulfill their home based liabilities as well.
\end{abstract}

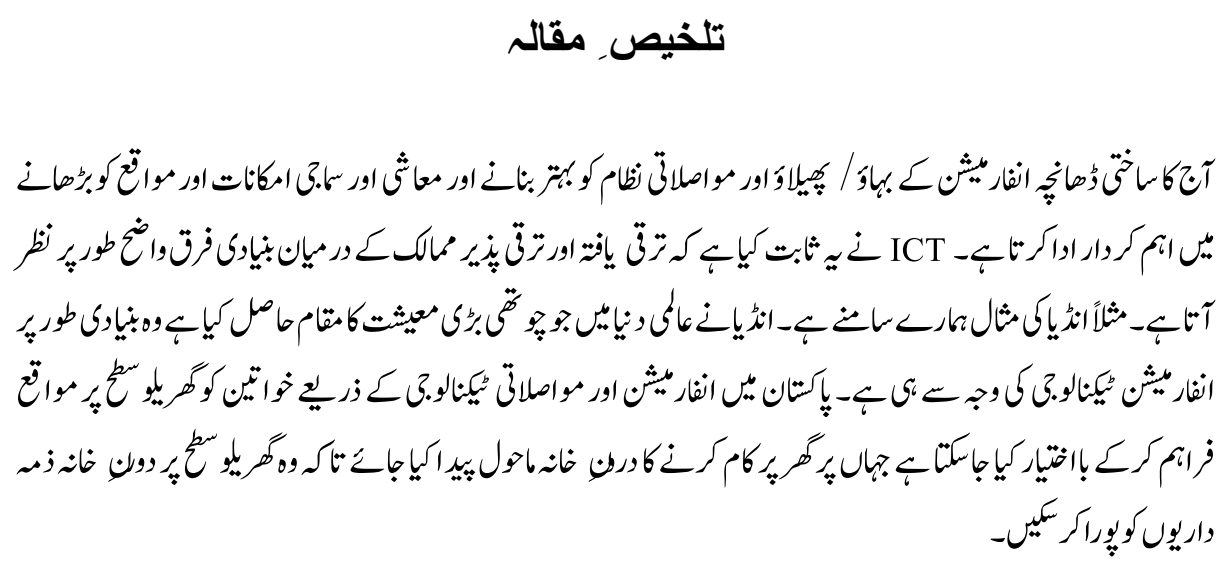

\section{Introduction}

The recognition of new and wide possibilities that technology presents in our modern times has increased greatly. IT and Communication and technologies have brought a total revolution and brought about unprecedented changes in the ways people conduct business, 
socially interact and communicate. This development of new technologies and the evolution of new and old technologies have made the lives of people better and comfortable in a number of ways. This has also led to the belief that aside from this single track technology, integration of technologies can yield to gain impressive results and all the world is currently in this direction. The impact of internet is such that people have almost forgotten how it was to work without it. Nothing has had such an impact throughout the course of human existence. It has changed every aspect of our life. It has changed how we live, interact, conduct business, and more or less everything.

Information and communication technologies (ICTs) have changed every aspect of our life; be it community radios in the most remote parts of the world, to cell phones in the hands of everyone and to computers in large and medium size organizations. This improvement in ICTs has brought opportunities for knowledge sharing and gathering. This has caused the global community to reach to unconnected people and populations to understand them better and address their issues effectively. Through the use of innovative ideas and tools, ICT has provided us with infinite opportunities for economic and social development.

\section{Women and Technology}

Even though women adopted new technologies after some time, they still have narrowed the gap in recent years. Women can benefit from ICT in a number of ways. It greatly eases their participation in different sectors and regions. It provides women with the information to improve their wellbeing and that of their families (Ana M. González Ramos, 2011).

The scope and quality of work for women in IT related fields has improved due to the introduction of computers in offices. Due to its low cost ICT can directly empower women by offering access to services which were not available to them in the past. Even just buying and selling ICT equipment is itself a source of income. Being an enormous source of information, ICT becomes a powerful tool that provides access to marketing information. It also is a cheap means of sharing knowledge for women organizations. It allows them to exchange opinions, information and views which might not be possible through any other medium. Especially for women in developing countries IT can offer significant opportunities.

\section{ICT and Empowerment of Women:}

ICT provides a ton of opportunities to men and women both that simply can't be ignored. We have the power to change the world and live out our dreams. This opportunity can't be missed. ICTs hold knowledge and resources that has a tremendous potential for 
women empowerment. Like all things, there are certain challenges associated with it. There is a belief that women are empowered through the learning and use of ICTs has been adopted globally. Due to this many governments and agencies have started a number of courses and training available to women everywhere around the world.

So does ICT promote gender equality and empower women? There is recognition of the potential of ICT as a tool for the promotion of gender equality and the empowerment of women. A number of women have made significant contribution through ICT (Clem Herman, 2010). But does this means that ICT automatically empowers women or reduces gender in-equality? The answer would be negative. A large number of women are outside the loop, due to two major factors; Illiteracy and the Poverty rate in the Pakistan.

Research indicates that ICT creates an environment for economic growth. It also facilitates and improves education, business and employment opportunities. It is essential to ensure that women especially of developing countries understand the significance of these technologies and contribute in the development of their country, or else they will be further removed from the mainstream of their countries. For a sustainable world the empowerment of women is necessary. The world needs the ideas of women to reduce poverty and to improve healthcare etc. Without women empowerment all of this is a dream. But reality is that most women lack the technical know-how and resources to access such tools and how to fully utilize them. These also have an impact in determining wage potential. In USA alone workers who use ICT are paid $10-15 \%$ more than noncomputer users holding similar positions. This shows that those individuals who have no expertise in new technology will be further marginalized (Elayne Clift, 2010).

\section{ICT and Women in Pakistan}

ICT can be a great catalyst in the development of Pakistan and the development \&empowerment of women in the country. ICT provides many features for the prosperity and empowerment of women in the country. Facilities available for women through ICT include E-learning, E-shopping, Freelance careers, Social networking, awareness of the latest development in the country and other trending developments. Unfortunately, in Pakistan, ICT services cannot be availed by the majority of the Women in the country.

\section{Illiteracy}

"Educate a man and you educate a person; educate a woman and you educate a family" (Proverb). Women are the most important part of a family and the nation, and as the quote goes by, educated women are as important in the society as are the educated men. Educate the men, not the women; the society will not progress. Educate the women, the men will get educated and so will be the women and the society progresses. The history 
has seen, when the women were left uneducated, the men deviated from the course of rectitude and luxuriated. Only great and educated mothers can give you a great and progressive society. Below listed is a chart which shows the population of Pakistan and gender ratio in rural and urban areas (based on census data of Government of Pakistan Year 1998, issued by the Census Bureau, Government of Pakistan)

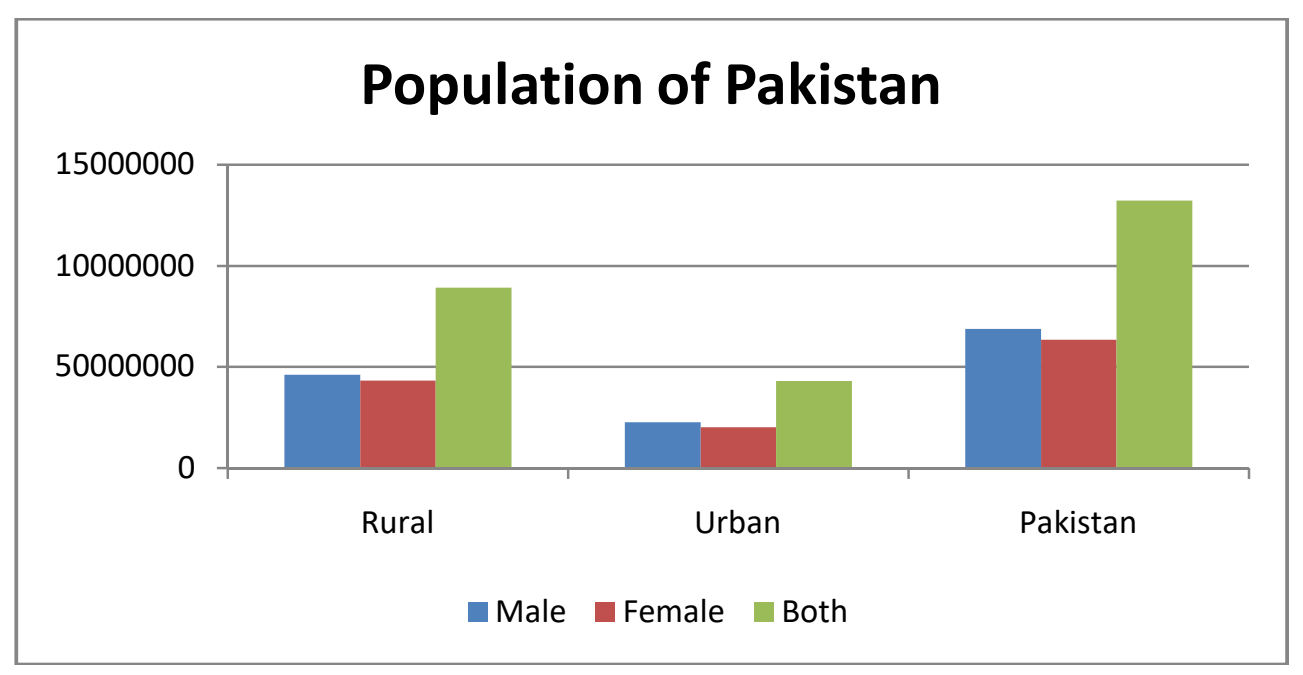

Sadly, it's hard to mention but it's true that, Women constitutes of $48 \%$ of the population of Pakistan and 55\% of these women are not even literate enough to write a simple letter in any language (the data represented in the chart is based on a survey which is conducted by the Government of Pakistan). When such is the situation exists, progress and development of nation is a day dream.

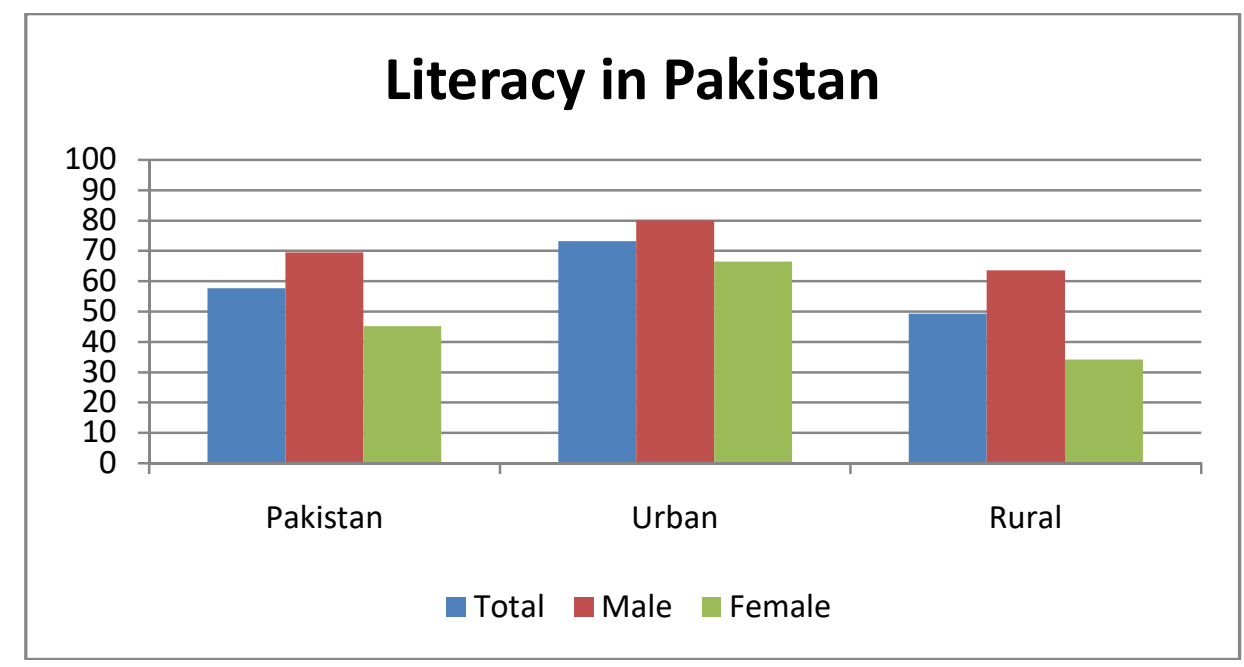


The Abysmal literacy situation of the country overshadows all the positive factors of the ICT even with the ICT infrastructure currently available in the country. ICT provides many benefits and bright prospects for the progress and development of women in the country but requires the subject to be able to read and understand. ICT can enhance the knowledge quality but the basic requirements for acquiring the knowledge should be fulfilled (GambhirBhatta, 2010).

The Literacy rate also varies greatly among the provinces (as shown in the following chart, whose statistical measures are based on survey conducted by the Government of Pakistan. Data available at www.pak.gov.pk, Year 1999) and thus also constitutes a way towards the lack of ability to avail the ICT provided opportunities and the progress and empowerment of Women in the country.

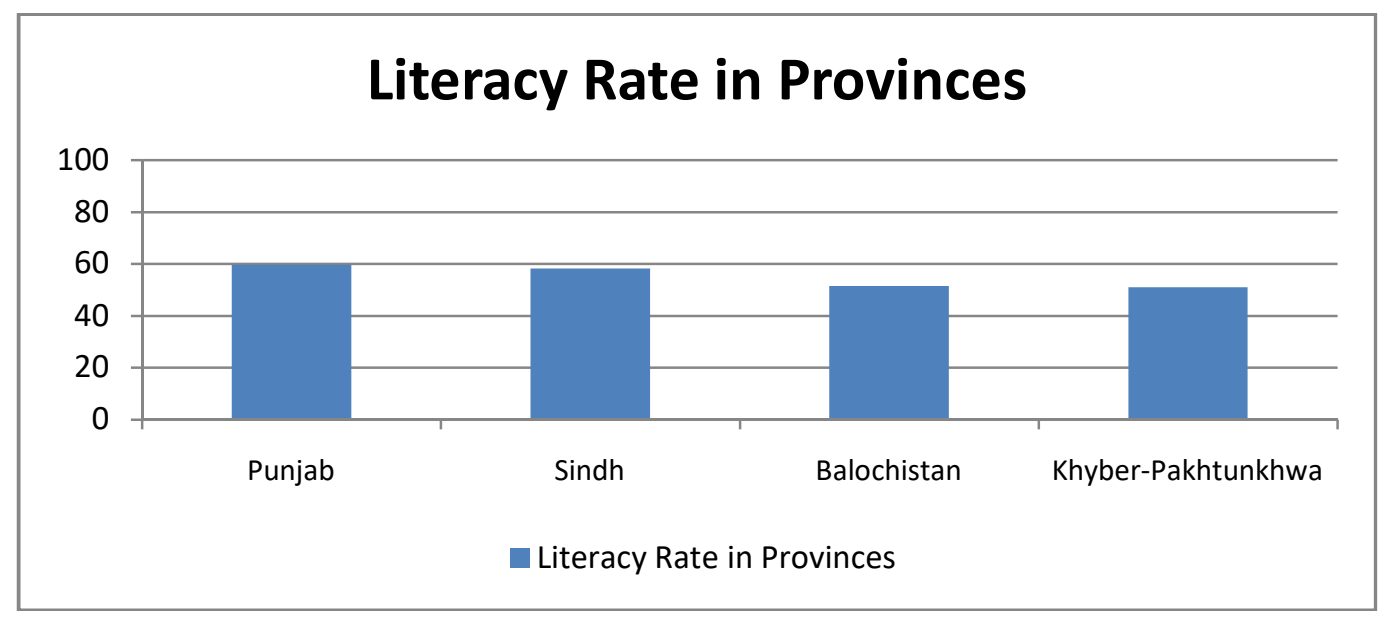

This literacy rate doesn't even provide the bleakest of the pictures of the real prevailing situation of the education in the country. Hardly $10 \%$ of the educated population has passed the intermediate level, a level of education that is easily being passed by $70 \%$ population in developed countries. This situation is more dreadful when you consider the quality of the education and the merit of the education in country. Use of unfair means is exceedingly common in the exams at the matriculation and intermediate level. (Year 1999, Source Ministry of Education, Sindh Government Website) 


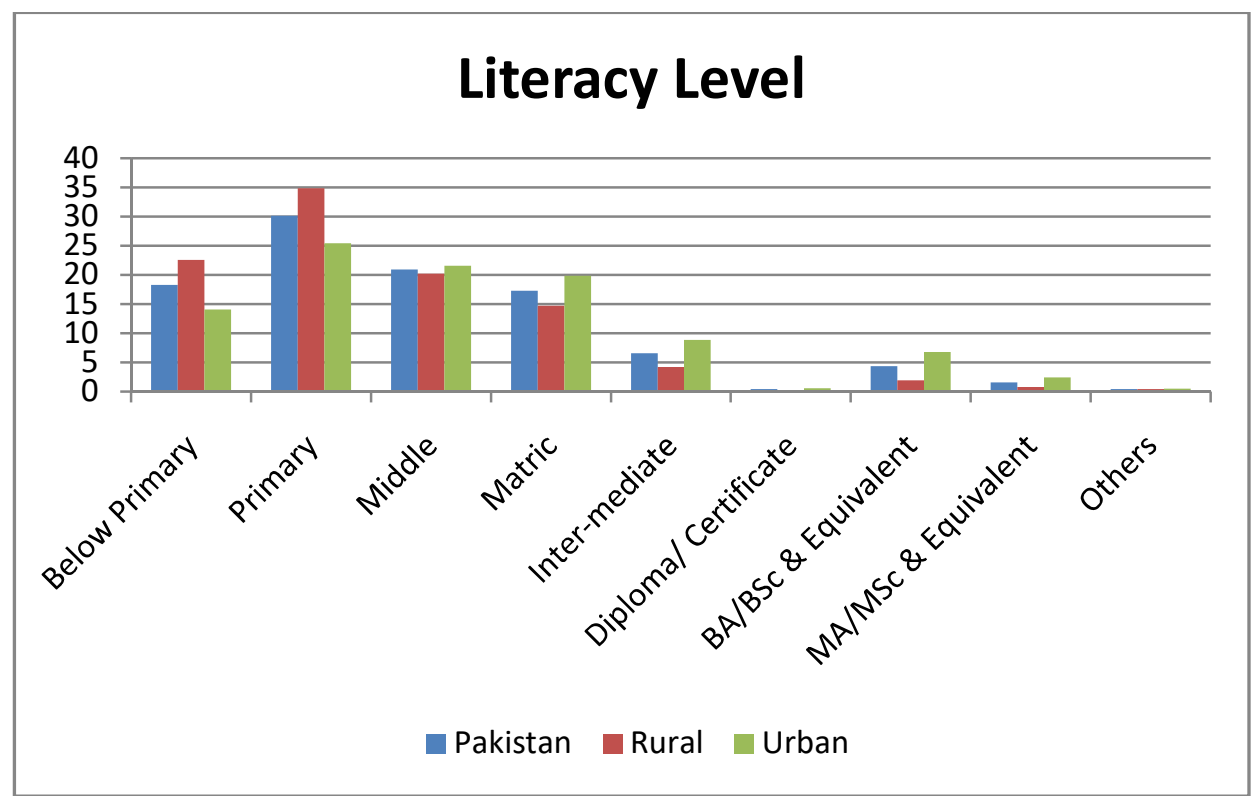

\section{Gender Discrimination}

Gender discrimination (Clem Herman, 2009) is another key factor that affects the literacy situation of women in the country and it also relates the access and availability of ICT opportunities for women in the country. Gender discrimination fueled through to the illiteracy among the men population needs to be abolished,so that women may get equally benefitted by the ICT powered facilities (Terri Whittaker, 2010). The Literacy ratio between males and females in the country is $55.7 \%$ and $45.2 \%$ respectively. There is about (22) Twenty Two million internet users in the country and about $30 \%$ of them are women [as per the survey data of the Pakistan Software Export Board (PSEB), \& Pakistan Software Houses Association (PASHA)]

\section{The Happy Part}

ICT in Pakistan might not be very helpful for the empowerment and progress of women for the majority of women population as per the current situation in Pakistan, but still is quite effective for the ones who can avail it. ICT provide many benefits to the literate in society and has raised the quality of life bar by a lot for them. ICT also features a great deal of benefits for the women in the country. Some of the benefits for women in the country have been listed in the write-up that follows. 


\section{Knowledge \& Education}

As ICT has generally made the availability of Knowledge and Education much easier, simpler and comforter, the luxury is also available for the women. Hundreds of thousands of websites, discussion forums, and blogs continue to provide information and knowledge on quite diverse range of topics for everyone. The cores of the ICT atonements areinformation, knowledge and education which are also the most important constituents of a progressive society.

ICT facilities include e-learning which incorporates learning and teaching methods using electronically powered equipment in any form. The network and communication systems are used to implement the learning process, in most cases, in a distant learning environment (Goetz, A, 1996).

E-learning is an elegant, and a network-enabled transfer of adroitness and knowledge. Elearning structure includesvirtual education opportunities, computer-based learning, digital collaboration, and Web-based learning. Learning material can be delivered via the Optical Disks, intranet, Internet, audio or video tape, and satellite TV. It can be selfstriddenor instructor-stridden; itcan include media in the form of live conferences, animation, text, slides, image, and audio or streaming video (Buenafe R. Abdon, 2007).

Following are the two graphs that shows the percentage of educated population has access to the internet resources and the other graph shows the comparative analysis of the traditional versus E-Learning methods of teaching (for the educated population only) which clearly shows that if the E-learning methods of teaching should be adopted they will yield additional benefits and will definitely improve the learning curve of the overall nation (Buenafe R. Abdon, 2007) (source: Federal Ministry of Education Pakistan statistical web-content, http://fde.gov.pk/) 

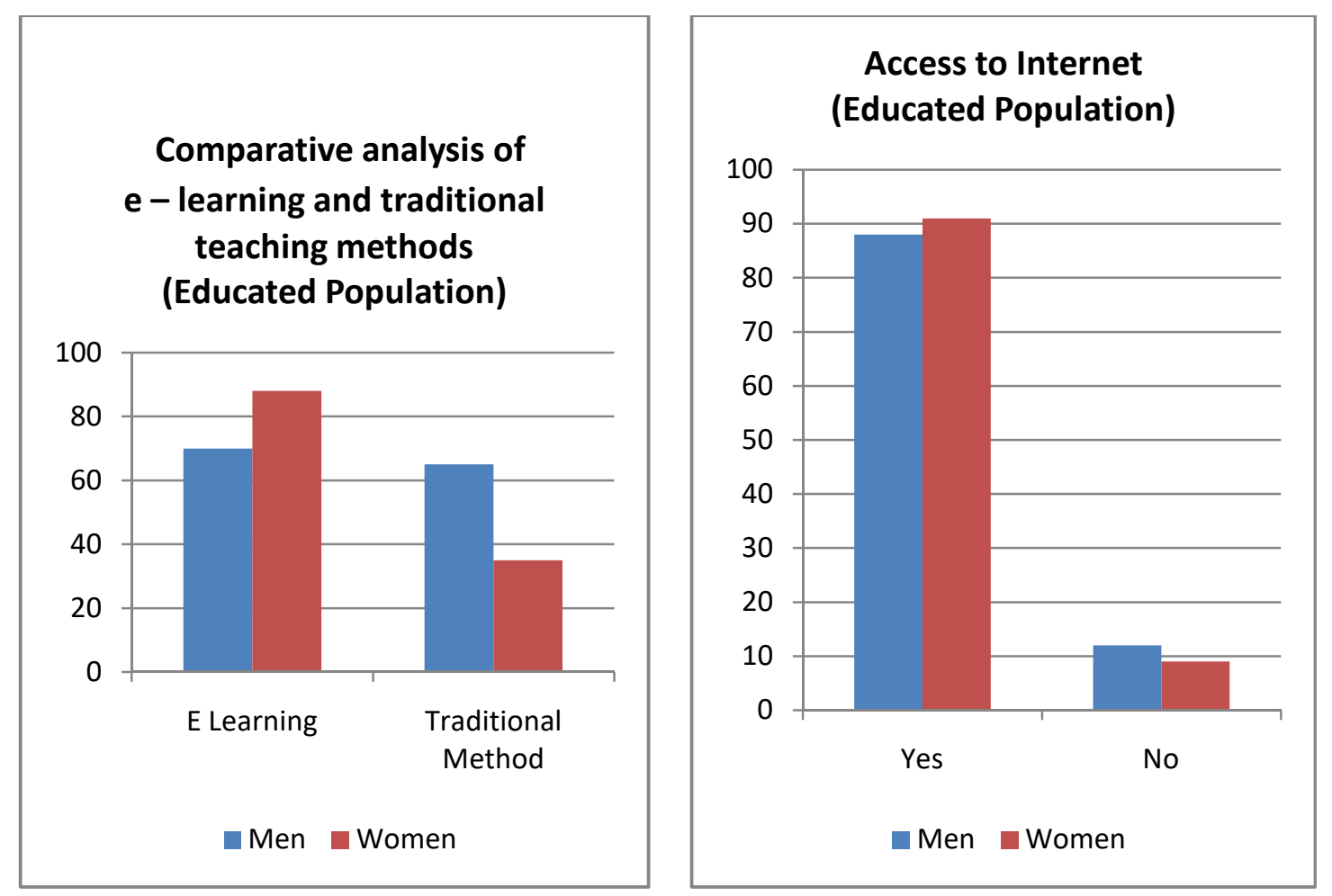

Traditional education in no way can be replaced by the new technologies, but it is popularly believed that the new technologies can strongly assist in education. The new generation can use the great interactivity of the new media and smart devices, to develop their skills, increase their knowledge and their perception of the globe. Although under an adult's supervision, and that too for many reasons; the type of content available, the credibility of the content, and the vast majority and flavors of the content, that will confuse the younger minds, thus needs to be consistently monitored by the trained personnel.

Chart that present the e-learning / traditional learning comparison (based on a survey conducted by the professional researchers) shows that the e-learning bar is comparatively higher as compared to the traditional learning methodologies, which shows that it's adaptability is much higher as compared to traditional learning methodologies, it is easy to visualize that, the e-learning methodology isneither based on time line nor it is having a specific location, declared as the learning center (any one can view the lectures or content at anytime from anywhere), thus having higher acquiescence ratio.

It can also be observed from the Frequency \& Purpose of Internet use Bar Charts that the literate population use internet as primary connection and information content delivery channel, so this could become the most popular and adapted methodology for the transfer 
of knowledge \& skills and could be used for improving the literacy rate in Pakistan thus leading the way for the women population empowerment.
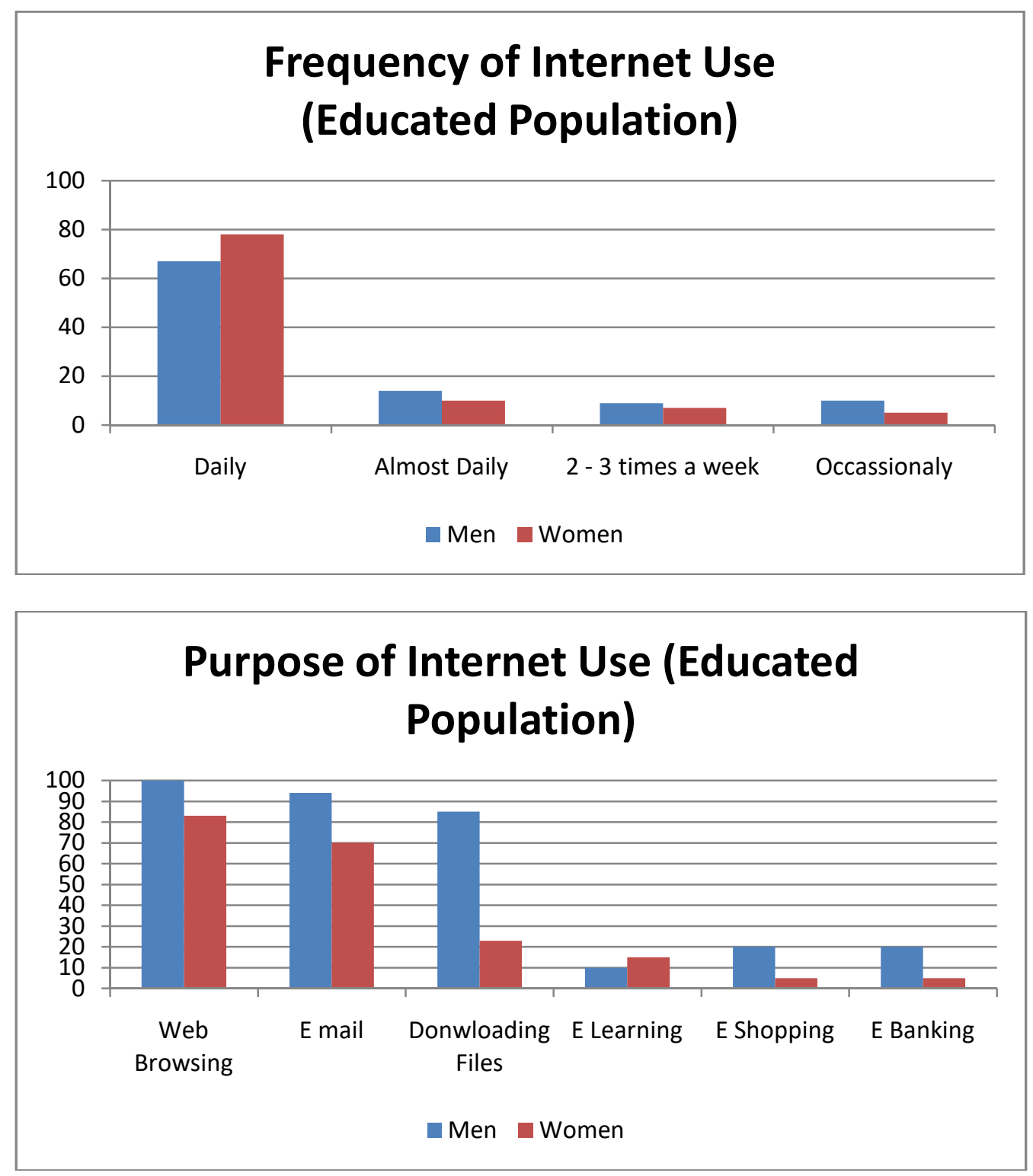

\section{E-Jobs and e-Work}

As ICT has drastically changed the conventional work style in the past decade and a half; it has also opened many jobs for the public. The ICT jobs are equally available for the women and have also opened a brand new door of jobs, which have great benefits and 
pleasure for women. The concept of working from a remote location is a feature of ICT that is applauded by a large proportion and gives women the luxury of working even from home, without the hustle of arriving at a workplace. ICT has also promoted many freelancing jobs, which do not require you to have any office, or a conventional workplace and can be completed from locations at your ease and at timings you prefer. This is a great opportunity for women to participate in the income of the family and providing with enough free time and control to fulfill the house chores (Pitt, Mark M., 2006). The opportunity also complies with our society norms where the women need to look after the children and prepare thevictuals as well. It should be promoted by all sectors of the society and women should be encouraged to freelance whenever the opportunity is available.

\section{Discussion Boards\& Bulletin Boards:}

Digital Discussion boards are an eminentproduct of ICT. Discussion boards allows the people to share their views on wide variety of topics, thus it will empower women with a variety ranging from political topics, latest \& breaking news, sports, travelling, cooking, fashion, shopping and decoration among many others. This could greatly benefit the literacy rate \& psychosomatic maturity of the women based population in Pakistan, as electronically certain discussion could be made available on which certain domain experts are not easily available, so when the subject specialist gets some time they could post their knowledge base on a certain bulletin board and further the domain sub-experts could extend the experts advise and knowledge base. Whereas the bulletin boards keep them updated with the current news and views, \& the latest developments in health care, fashion apparel, industrial exposuresetc (Jacki Proctor, 2010).

\section{Social Networking / E-Socio-Working}

Social Networking Websites are anillustriousproduct of ICT in the current time less era. They allow for maintaining one's social networks and keep up the communication efficiently even at physical distances of thousands of kilometers. Even when you are inside the house, you are not alone and can connect with people with whom no feasibility of physical meet up is possible. Social Networking allows you to be socially active and vocal even if you are in your home. As per our scenario Urban women are use-to with the facilities and concept of Social Networking and they are having hundreds of people in their social network over different social networking sites with whom they can share their social dealings or even can bargain or have a business deal, most commonly used business deals over social networks in Urban areas are related to boutiques and fashion apparels, where as the concept of social network is still in need of overture for the rural women where "no" or "very less" Information \& communication resources are available for people specially for the women (because of male dominant society, high illiteracy rate, 
and issues of "character integrity" for women), but if the information \& communication resources would be provided to the rural women they could better network with their neighboring counterparts in villages, they could better network with healthcare neighboring facilities (this could reduce infant mortality rate, one of theconflagration rural health issues), and they could have better chances of promoting their handicrafts and precious crafted relics with a superior likelihood of vanquishing new market segment with virtuous value with the help of their connectedchums (Sarah Oerton, 2010).

\section{Blogs}

Blogs are a great way for women to express their opinion and let the world be aware of their prospects. Blogs in recent times had been a key part in many uprisings against wellestablished governments in Tunisia, Egypt, Bahrain and Syria. Women took aggressive part in the blogs as a way to express their views against the socio-economic squander of nation by the blasphemous and sacrilegious ruling people and thus women were at the core of the revolution in the countries like Egypt, Syria etc. Blogs offer great benefits to a common person. Blogs gives you the ability to pursue your passion; Blogs provide you a platform to start with. Blogs refine your writing skills. Blogs increase your connectivity with likeminded people. Blogging not only increases your knowledge base but it also solves problems for other people. Blogging increases ones thinking and communicating capabilities. Most importantly, they give you a voice and earning opportunities.

\section{Communication}

A great set of features provided by ICT are the means of communication provided by it. VoIP (Voice over Internet Protocol) and other video calling techniques have really turned world into a global village. These means of communications are easily available for use by the women in the country. These means of communication have provided women a great facility. They can communicate with any one over very long distance without any hurdle and at quite cheap prices. There are numerous ways the ICT has improved the communications. Mobile phones are now a days the primary tool for communicating at short and long distances. Smartphones now days have started to replace the conventional mobile phones and provide a lot more ICT features than the conventional mobile phones. Internet has provided many forms of communications. Email being one of the oldest forms, which is primarily used now for formal communications. Software Such as Skype, yahoo messenger and Google talk allow people on the internet to communicate easily and without any cost. VoIP software allows people to communicate with people on mobile phones through Internet at very cheap costs. Thus the concept of physical place less office became a reality, as the VoIP and other related methods provide the cheapest means to the women in society to communicate, as if they were conducting business it helps them in remote marketing and / or coordinating with the follows working at the 
physical marketing locations, the ICT tools help them connect with the other colleagues or subordinates while they are working or directing the business from home, thus it proves to be aauthoritative channel of empowering women.

\section{Political Empowerment}

To strengthen democracy and improve governance, IT can prove to be a powerful tool. It is particularly powerful for giving voice to women who are isolated, invisible and without a voice. As a tool for bridging, to perform social and political advocacy, to ensure women participation in the political process IT can be quite a powerful tool. It can also be a tool to improve women's access to government services. Political Empowerment force of the ICT can be witnessed by the current Arab spring uprisings and other anti-capitalist movements in the western society. ICT was the key factor in the uprisings and toppling of monarchs who had been ruling for decades in Tunisia, Libya, Egypt, Bahrain, Saudi Arabia, Yemen and Syria. (web source: Central Intelligence Agency (CIA, USA) https://www.cia.gov/library/publications/the-world-factbook/geos/ly.html)

\section{What needs to be done?}

To take advantage of such opportunities depends upon conducive policies and an environment which extends communication infrastructure where women live, special focus to be done for those women segments that live in rural / remote areas. Also, women of developing countries like Pakistan need to involve themselves in the learning of useful technologies for personal/family use and in thus provide their share for the making of IT policies.

The major obstacles for women in the country in the way of progress and empowerment are the lack of literacy and the gender discrimination, and in Pakistan the most important "the ethical integrity of women" a by-product of illiteracy in the male population. Concrete measures are required to eliminate illiteracy in the country. Although increasing illiteracy rate in the country and the promotion of Education in the country is not as easy and simple as may be written or propagated in speeches. The hurdles behind them are a lot politically motivated, religiously aggravated, traditionally lubricated and the liberally extremist version provided by the extreme leftist which tries to shatter the traditional and cultural though bigoted perspective of the society in a go.

To improve the literacy rate in the country should be the foremost priority of the government of Pakistan. An educational emergency is much needed in the country. Only when the basic education is provided properly to the majority of the women in the country and it needs to be provided in a way that doesn't try to shatter the bigoted 
traditions in a single strike as that doesn't happens. Change needs to be developed in the society rather than being imposed on the society through force.

Subsequently, the quality of education needs to be improved. The current quality of the education provided by the existing curriculum is outdated and is inadequate for the country to progress. The examination pattern and supervision needs to be revolutionized for the education imparted to be effected.

Concurrently, ICT awareness should be raised and propagated in the society through the media, the current educational system and by the civil society and political parties. Topics about ICT and Computer Sciences that are thought to our kids in the current curriculum are extinct. ICT has progressed to a whole new level. The mainstream educational curriculum needs to be revised and updated on yearly or at most three yearly bases to give the new generation a good grasp of the productivity of the ICT provided facilities (Clem Herman, 2010).

Development of ICT infrastructure is of significant importance. The current ICT infrastructure is becoming extinct. $2 \mathrm{G}$ cellular technologies that are currently being provided has been replaced by $4 \mathrm{G}$ technologies, a long time ago and better technologies yet are being introduced. Currently Common copper cables have been replaced by the fiber optics. A developed and up to date ICT infrastructure will have significant role in the progress and empowerment of women through ICT once the above mentioned and pre requisite of progress are achieved.

\section{Conclusions}

ICT can ensure gender equality and empower women in the country, given the literacy rate and educational status of a common person is improved andadequate ICT infrastructure is provided along with the condition thatpolicies should be established that promote the ICT services. And the Nation has the desire! The desire for a change! The desire for a better Pakistan.A country, which would be the symbol of Unity, Peace, Harmony and Humanity. A Developed and Progressive Pakistan; where the empowered women could play a leading and vital role in the escalation and fruition of Pakistan.

\section{References}

Ana M. González Ramos, NúriaVergés Bosch, "Moving for What? International Mobility Strategies of Women in ICT Careers", International Journal of Gender Science \& technology, Vol 3, No 2 (2011). 
Buenafe R. Abdon, Seishi Ninomiya, and Robert T. Raab, "E-Learning in Higher Education Makes Its Debut in Cambodia: The Provincial Business Education Project", Vol 8, No 1 (2007), International Review of Research in Open and Distance Learning

Clem Herman, "Review of "Women and Information Technology: Research on Underrepresentation", International Journal of Gender Science \& technology, Vol 2, No 3 (2010).

Clem Herman, Jenni Carr, "Current Issues for Gender and SET: Perspectives from Research, Policy and Practice", International Journal of Gender Science \& technology, Vol 1, No 1 (2009).

Clem Herman, Juliet Webster, "Taking a Lifecycle Approach: Redefining Women Returners to Science, Engineering and Technology", International Journal of Gender Science \& technology, Vol 2, No 2 (2010).

Elayne Clift \& Vicki Freimuth, "Changing women's lives: A communication perspective on participatory qualitative research techniques for gender equity", Journal: Journal of Gender Studies, Volume 6, Issue 3, November 1997, pages 289-296. Version of record first published: 28 Apr 2010

GambhirBhatta, "Of Geese and Ganders: Mainstreaming gender in the context of sustainable human development", Journal: Journal of Gender StudiesVolume 10, Issue 1, March 2001, pages 17-32. Version of record first published: 03 Aug 2010

Goetz, A. and R. Sen Gupta (1996). "Who Takes Credit? Gender, Power and Control over Loan Use in Rural Credit Programs in Bangladesh". World Development.24: 1.pp.45-63.

Jacki Proctor \& Christine Jackson, "Senior women managers and processes of change in the National Health Service", Journal: Journal of Gender Studies Volume 3, Issue 2, July 1994, pages 197-204. Version of record first published: 28 Apr 2010

Lemire, B., Ruth Pearson and Gail Campbell.eds. (2002). "Women and Credit: Researching the Past, Refiguring the Future". Oxford: Berg.

Madhuri Sharma, "Review of Women and Science in India", International Journal of Gender Science \& technology, Vol 2, No 1 (2010) 
Mayoux, L. (2002). "Women's Empowerment versus Sustainability? Towards a New Paradigm in Microfinance Programmes" in Lemireet. al. eds. Chapter 14.pp.24570.

Pitt, Mark M. and KhandkerShahidur R. (2006).“Empowering Women with Microfinance: Evidence from Bangladesh".Economic Development and Cultural Change.pp.791-831.

Sarah Oerton, "Exploring women workers' motives for employment in cooperative and collective organizations", Journal: Journal of Gender Studies, Volume 3, Issue 3, November 1994, pages 289-297. Version of record first published: 28 Apr 2010

Terri Whittaker, "Violence, gender and elder abuse: Towards a feminist analysis and practice", Journal: Journal of Gender Studies, Volume 4, Issue 1, March 1995, pages 35-45. Version of record first published: 28 Apr 2010

\section{Acronyms}

$\begin{array}{ll}\text { E-Learning } & \begin{array}{l}\text { Electronic Learning } \\ \text { E-Shopping }\end{array} \\ \text { Free Lancer } & \begin{array}{l}\text { Electronic Shopping } \\ \text { Person working for personal benefit without being } \\ \text { employed by a company } \\ \text { Information and Communication Technology } \\ \text { ICT }\end{array} \\ \text { ISP } & \text { Information Technology } \\ \text { IT } & \text { Percentage of persons who have the ability to read for } \\ \text { Literacy Rate } & \text { knowledge, writes coherently, and think critically about the } \\ & \text { written word } \\ \text { PASHA } & \text { Pakistan Software Houses Association } \\ \text { PSEB } & \text { Pakistan Software Export Board } \\ \text { Social Networking } & \text { Online service, platform, or site that focuses on facilitating } \\ & \text { the building of social relations among people }\end{array}$

S. M. Khalid Jamal is Assistant Professor in the Department of Computer Science, University of Karachi. 